International Journal of Current Advanced Research

ISSN: O: 2319-6475, ISSN: P: 2319 - 6505, Impact Factor: SJIF: 5.995

Available Online at www.journalijcar.org

Volume 6; Issue 4; April 2017; Page No. 3211-3213

DOI: http://dx.doi.org/10.24327/ijcar.2017.3213.0228

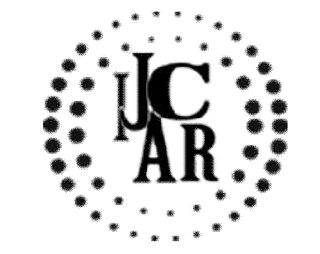

Research Article

\title{
STUDY OF LIVER FUNCTION TESTS IN HYPERTHYROID PATIENTS
}

\section{Navneet Kour., Meenakshi Sharma and Sunil Sachdev}

Department of Physiology, Government Medical College, Jammu

\begin{tabular}{l}
\hline A R T I C L E I N F O \\
Article History: \\
Received $11^{\text {th }}$ January, 2017 \\
Received in revised form $19^{\text {th }}$ February, 2017 \\
Accepted $22^{\text {nd }}$ March, 2017 \\
Published online $28^{\text {th }}$ April, 2017
\end{tabular}

Key words:

Liver function tests, hyperthyroidism

\begin{abstract}
A B S T R A C T
Aim: To study liver function tests in hyperthyroidism

Materials and Methods: 80subjects in the age group of 20-65 years were taken from the outpatient department of Government Medical College, Jammu and liver function tests including serum alanine aminotransferase, serum aspartate aminotransferase, serum bilirubin and serum albumin were evaluated in these subjects. Thyroid function tests were also determined.

Results: There is significant difference in mean AST (aspartate aminotransferase) and mean ALT (alanine aminotransferase) between euthyroid and hyperthyroid subjects whereas there is no significant difference in mean total bilirubin and mean total serum albumin between euthyroid and hyperthyroid subjects.

Conclusion: Thyrotoxicosis has a significant effect on liver that is reflected in increased level of liver specific enzymes i.e. AST and ALT.
\end{abstract}

Copyright $(2017$ Navneet Kour. This is an open access article distributed under the Creative Commons Attribution License, which permits unrestricted use, distribution, and reproduction in any medium, provided the original work is properly cited.

\section{INTRODUCTION}

Thyroid hormones are required for normal growth, development and function of nearly all tissues with major effects on oxygen consumption and metabolic rate (Yen, 2001). Disorders of thyroid gland results primarily from autoimmune processes that either stimulate the overproduction of thyroid hormones or cause glandular destruction and hormone deficiency (Larry Jameson and Anthony Weetman, 2005). Thyroid disease constitutes the most common endocrine abnormality in recent years, diagnosed either in clinical or sub-clinical form (Hollowell, Staehling and Flanders et al., 1988-1994). Liver is known to synthesize a number of plasma proteins that bind the lipophilic thyroid hormones (Youssef and Mullen, 2002). Also, liver is the major site for cholesterol and triglyceride metabolism and thyroid hormones play an integral part in hepatic lipid homeostasis (Ness et al.,1998). In addition to the central role in deiodination to activate and deactivate thyroid hormones, the liver performs specific functions relating to thyroid hormone transport and metabolism (Murray, 1974). Clinical features of hyperthyroidism are diverse, involving nearly every system in the body and can be conveniently divided into hepatic or cholestatic disease. The mechanism of hepatic injury appears to be relative hypoxia in the periventricular regions, due to an increase in hepatic oxygen demand without an appropriate increase in hepatic blood flow. In mild cases, liver histology shows nonspecific changes, consisting of a mild lobular inflammatory infiltrate

*Corresponding author: Navneet Kour

Department of Physiology, Government Medical College, Jammu consisting of polymorphic neutrophils, eosinophils and lymphocytes, associated with nuclear changes and kupffer cell hyperplasia(Huang and Liaw, 1995). In patients with cholestatic injury, histological features are similar to nonspecific changes seen in hepatic injury. However,in addition ,there appears to be centri-lobular intrahepatocytic cholestasis (Sola et al.,1991).Increase in AST and ALT may be induced by changes in thyroid function(Kubota et al., 2008). So, the present study is planned to access the effects of hyperthyroidism in perturbing liver functions.

\section{MATERIALS AND METHODS}

80 subjects were taken from outpatient department of Government Medical College, Jammu in the age group of 2065 years. Subjects were divided into 2 groups of 40 euthyroid and 40 hyperthyroid patients. All subjects with pre-existing diseases like diabetes mellitus, renal disorders or any other chronic inflammatory medical conditions were excluded from the study. Physical measurements like weight in $\mathrm{kgs}$ and height in (meters) were taken. Thyroid function tests (T3, T4 and TSH) were estimated in human serum and plasma by chemiluscent microparticle immunoassay (Patel et al.,1972; Sterling and Lazarus,1977). In estimation of T3,T4 and TSH, ARCHITECT Total T3 Reagent Kit (7K64), ARCHITECT Total T4 Reagent Kit (7K66) and ARCHITECT Total TSH Reagent Kit (7K62) were used respectively. Liver function tests (albumin estimation, alanine aminotransferase, aspartate aminotransferase, serum bilirubin estimation) were estimated in plasma by using chromatic endpoint technique. Albumin estimation is an adaptation of the bromocresol purple dyebinding method (Carter,1970; Louderback et al.,1968). 
Standard procedures for specimen collection and storing were used. The liver function tests were assessed according to Clinical Diagnosis and Management by Laboratory Methods (Henry, 2003).

\section{Statistical Analysis}

Data was subjected to one way analyses of variance (ANOVA, Kyplot version 2). In all the cases, means are used as units of analyses and are represented as Mean \pm SD. A pvalue of less than 0.05 was considered statistically significant.

\section{RESULTS}

Table 1 Comparison of mean total billirubin of euthyroid and hyperthyroid subjects.

\begin{tabular}{|c|c|c|c|c|}
\hline \multirow{2}{*}{$\begin{array}{c}\text { Classification } \\
\text { of subjects }\end{array}$} & $\begin{array}{c}\text { T. Bilirubin } \\
\text { (mg\%) }\end{array}$ & $\begin{array}{l}\text { Statistical } \\
\text { inference }\end{array}$ & $\begin{array}{l}\text { Statistical } \\
\text { inference }\end{array}$ & \multirow{2}{*}{$\begin{array}{l}\text { Significant } \\
\text { difference }\end{array}$} \\
\hline & Mean \pm SD & F-value & P-value & \\
\hline Euthyroid & $0.54 \pm 0.24$ & & \multirow[t]{2}{*}{$\mathrm{P}=0.2635$} & $\begin{array}{c}\text { Not } \\
\text { Significant }\end{array}$ \\
\hline Hyperthyroid & $0.49 \pm 0.16$ & $F_{(1,78)}=1.2687$ & & as $\mathrm{P}>0.05$ \\
\hline
\end{tabular}

Table 2 Comparison of serum albumin of euthyroid and hyperthyroid subjects

\begin{tabular}{ccccc}
\hline $\begin{array}{c}\text { Classification } \\
\text { of subjects }\end{array}$ & $\begin{array}{c}\text { S. Albumin } \\
(\mathbf{m g} \%)\end{array}$ & $\begin{array}{c}\text { Statistical } \\
\text { inference }\end{array}$ & $\begin{array}{c}\text { Statistical } \\
\text { inference }\end{array}$ & $\begin{array}{c}\text { Significant } \\
\text { difference }\end{array}$ \\
\cline { 2 - 4 } Mean $\pm \mathrm{SD}$ & F-value & $\mathrm{P}$ - value & \\
\hline $\begin{array}{c}\text { Euthyroid } \\
\text { Hyperthyroid }\end{array}$ & $3.87 \pm 0.36$ & & $\mathrm{P}=0.3048$ & $\begin{array}{c}\text { Not Significant } \\
\text { as } \mathrm{P}>0.05\end{array}$ \\
\hline
\end{tabular}

Table 3 Comparison of mean AST levels of euthyroid and hyperthyroid subjects

\begin{tabular}{ccccc}
\hline $\begin{array}{c}\text { Classification of } \\
\text { subjects }\end{array}$ & $\mathbf{A S T}(\mathbf{I U} / \mathbf{L})$ & $\begin{array}{c}\text { Statistical } \\
\text { inference }\end{array}$ & $\begin{array}{c}\text { Statistical } \\
\text { inference }\end{array}$ & $\begin{array}{c}\text { Significant } \\
\text { difference }\end{array}$ \\
\cline { 2 - 5 } & Mean \pm SD & F-value & P-value & \\
\hline $\begin{array}{c}\text { Euthyroid } \\
\text { Hyperthyroid }\end{array}$ & $34.18 \pm 7.68$ & & $\mathrm{P}=0.0001$ & $\begin{array}{c}\text { Significant } \\
\text { as } \mathrm{P}<0.05\end{array}$ \\
\hline
\end{tabular}

Table 4 Comparison of mean ALT levels of euthyroid and hyperthyroid subjects.

\begin{tabular}{ccccc}
\hline $\begin{array}{c}\text { Classification of } \\
\text { subjects }\end{array}$ & ALT (IU/L) & $\begin{array}{c}\text { Statistical } \\
\text { inference }\end{array}$ & $\begin{array}{c}\text { Statistical } \\
\text { inference }\end{array}$ & $\begin{array}{c}\text { Significant } \\
\text { difference }\end{array}$ \\
\cline { 2 - 5 } & Mean \pm SD & F-value & P-value & \\
\hline Euthyroid & $35.7 \pm 10.54$ & & $\mathrm{P}=0.0001$ & $\begin{array}{l}\text { Significant } \\
\text { as } \mathrm{P}<0.05\end{array}$ \\
Hyperthyroid & $46.45 \pm 12.91$ & $\mathrm{~F}_{(1,78)}=16.6364$ & & \\
\hline
\end{tabular}

Table 1 shows euthyroid subjects have mean total bilirubin $0.54(\mathrm{SD} \pm 0.24) \mathrm{mg} \%$. Hyperthyroid subjects have mean total bilirubin $0.49(\mathrm{SD} \pm 0.16) \mathrm{mg} \%$. There is no significant difference in mean total bilirubin between euthyroid and hyperthyroid subjects. Table 2 shows euthyroid subjects have mean albumin levels of 3.87 ( $\mathrm{SD} \pm 0.36) \mathrm{mg} \%$. Hyperthyroid subjects have mean albumin levels of $3.95(\mathrm{SD} \pm 0.39) \mathrm{mg} \%$. There is again no significant difference in mean albumin levels of euthyroid and hyperthyroid subjects. Table 3 shows euthyroid subjects have mean AST levels 25.18 (SD \pm 7.68 ) IU/L. Hyperthyroid subjects have mean AST level 34.48 (SD $\pm 11.37) \mathrm{IU} / \mathrm{L}$. There is significant difference in mean AST between euthyroid and hyperthyroid subjects. Table 4 shows euthyroid subjects have mean ALT levels 35.7(SD \pm 10.54 ) IU/L. Hyperthyroid subjects have mean ALT levels 46.45 (SD $\pm 12.91) \mathrm{IU} / \mathrm{L}$. There is significant difference in mean ALT between euthyroid and hyperthyroid subjects.

\section{DISCUSSION}

Thyroid hormones influence the function of all body organs and cells. The data presented here clearly indicates how biochemical markers of liver may be affected by alteration in the level of thyroid hormones in the body.Our findings are in consensus with the study by Ohshima et al., (1990) that liver has an important role in metabolism of thyroid hormone and autopsies have shown hepatic inflammation, fibrosis and centrilobular necrosis in patients with hyperthyroidism. Our study is also in accordance with the theory that thyrotoxicosis may cause a defect in bilirubin metabolism by decreasing bilirubin UDP-glucouronyl transferase (Greenberger et al., 1964). The physiological effects of hyperthyroidism may create increased hepatic oxygen consumption without an equal increase in blood flow, causing focal hypoxaemia and hepatic dysfunction (Venditti et al., 2006). It has also been hypothesized that these abnormalities are in part related to congestive heart failure and venous congestion caused by hyperthyroidism, although features of congestive hepatopathy were not evident in liver biopsy (Dooner et al., 1967). Thyroid hormones regulate the basal metabolic rate of all cells including hepatocytes and hence modulate hepatic function (Malik and Hodgson, 2002). Lim et al., 1993 in a study found that hyperthyroidism ia well documented cause of abnormal liver enzymes. The cases in the present study were mainly the referral cases from different outpatient departments of the hospital. A significant difference was observed in TSH, T3 and T4 levels of euthyroid and hyperthyroid patients.

\section{CONCLUSION}

We conclude that thyrotoxicosis has a significant effect on liver that is reflected in increased levels of AST and ALT levels.

\section{References}

1. Carter P. Ultramicroestimation of human serum albumin: binding cationic dye 5,5 dibromo-o cresolsulphonphthalein, Microchem J 1970; 15: 531539.

2. Dooner HP, Prada J, Aliaga C and Hoyl C. The Liver in Thyrotoxicosis. Arch Intern Med 1967; 120(1): 25 32.

3. Greenberger NJ, Milligan FD, Degroot LJ and Isselbacher KJ. Jaundice and Thyrotoxicosis in absence of congestive heart failure. A study of four cases. Am J Med 1964; 36: 840-6.

4. Henry JB. Evaluation of liver function. Clinical Diagnosis and Management by Lab Methods, $12^{\text {th }}$ edition 2003; 275-76.

5. Hollowell JG, Staehling NW and Flanders WD et al. Serum TSH, T4 and thyroid antibodies in the United States population (1988-1994): National Health and Nutrition Examination Survey (NHANES III) journal of Clinical Endocrinology and Metabolism 2002; 87(2): 489-499.

6. Huang MJ and Liaw YF. Clinical associations between thyroid and liver diseases. J Gastroenterol Hepatol 1995; 10: 344-50.

7. Kubota S, Amino N, Matsumoto Y, Ikeda N, Morita S and KudoT et al. Serial changes in liver function tests in patients with thyrotoxicosis induced by Grave's 
disease and painless thyroiditis. Thyroid 2008; 18: 283-7.

8. Larry J Jameson and Anthony P Weetman. Disorders of the Thyroid gland.In: Harrison's Principles of Internal Medicine. Mc Graw-Hill, (2005).

9. Lim CF, Docter R and Visser TJ et al. Inhibition of thyroxine transportinto cultured rat hepatocytes by serum of non-uremic critically ill patients: effects of bilirubin and non-esterified fatty acids. $J$ Clin Endocrinol Metab 1993; 76(5): 1165-72.

10. Louderback A, Measely EH and Taylor NA. A new dye binder technic using bromocresol purple for determination of albumin in serum. Clin Chem 1968; 14: 793-794

11. Malik $\mathrm{R}$ and Hodgson $\mathrm{H}$. The relationship between the thyroid gland and the liver. Q J Med 2002; 95: 559-69.

12. Murray. The thyroid. Quoted by: Mountcastle VB. In: Medical Physiology, vol.2, $13^{\text {th }}$ edition. Published by The CV Mosby Company, Saint Louis 1974; 16321633.

13. Ness GC, Lopez D, Chambers CM, Newsome WP, Cornelius P, Long CA and Harwood HJ Jr. Effects of L-triiodothyronine and the thyromimetic L-94901 on serum lipoprotein levels and hepatic low-density lipoprotein receptor, 3-hydroxy-3-methylglutaryl coenzyme A reductase, and apo A-I gene expression. Biochem Pharmacol 1998; 56: 121-9.
14. Oshima T, Maeda H and Takayasu $\mathrm{T}$ et al. [An autopsy case of sudden death due to hyperthyroidism]. Nihon Hoigaku Zasshi 1990; 44(4): 365-70.

15. Patel YC, Alford FP and Burger HG. The 24 hour plasma thyrotropin profile. Clin Sci 1972; 43: 71-77.

16. Sola J, Pardo-Mindan FJ, Zozaya J, Quirga J, Sangro B and Prieto J: Liver changes in patients with hyperthyroidism. Liver 1991; 11: 193-197.

17. Sterling K and Lazarus JH. The thyroid and its control. Annu Rev Physiol 1977; 39: 349-71.

18. Venditti $\mathrm{P}$ and Di Meo S.Thyroid hormone induced oxidative stress. Cell Mol Life and treatment of non-Hodgkin's lymphoma of the thyroid g land. Ann Surg Oncol 2001; 8: 338-41.

19. Yen PM. Physiology and molecular basis of thyroid hormone action. Physiol Rev 2001; 81: 1097-142

20. Youssef WI and Mullen KD. The liver in other (nondiabetic) endocrine disorders. Clinics in Liver Disease 2002; 6(4): 879-89.

\section{How to cite this article:}

Navneet Kour et al (2017) ' Study Of Liver Function Tests In Hyperthyroid Patients', International Journal of Current Advanced Research, 06(04), pp. 3211-3213.

DOI: http://dx.doi.org/10.24327/ijcar.2017.3213.0228 